\title{
Neonatal sepsis with neutropenia: granulocytecolony stimulating factor (G-CSF)
}

\author{
Antonio Silvinato ${ }^{1}$ \\ Wanderley Marques Bernardo² \\ Idevaldo Floriano ${ }^{1}$ \\ Gabriel Nogueira Bastos Soledade
}

1. Programa Diretrizes da Associação Médica Brasileira, São Paulo, SP, Brasil. 2. Coordenador do Programa Diretrizes da Associação Médica Brasileira, São Paulo, SP, Brasil.

http://dx.doi.org/10.1590/1806-9282.66.4.400

Question: What is the impact on overall mortality outcomes (death from any cause) and adverse events of g-csf in the treatment of newborns with neonatal sepsis and neutropenia [absolute neutrophil count (anc) $<5,000 \mathrm{~mm}^{3}$ ] compared to the conventional therapy?'

Answer: In newborns with sepsis and neutropenia $\leq 5,000$ cells $/ \mathrm{mm}^{3}$, the use of g-csf reduces the risk of in-hospital death by $19 \%(\mathrm{nnt}=5)$. G-csf has proved to be a safe drug.

\section{REFERENCES}

1. Silvinato $A$, Bernardo WB, Floriano I - Neonatal sepsis with neutropenia: granulocytecolony stimulating factor (G-CSF) - REV ASSOC MED BRAS 2020; 66(1):3-10. 